\title{
Congenital epulis with auto-resolution: case report
}

\author{
Epúlide congênita com auto-resolução: relato de caso
}

\author{
Adriane Sousa de SIQUEIRA' \\ Márcia Regina Dias de CARVALHO' \\ Ana Celina Dourado MONTEIRO' \\ Maria das Graças Rodrigues PINHEIRO² \\ Lucas Rodrigues PINHEIRO ${ }^{3}$ \\ João de Jesus Viana PINHEIRO ${ }^{1}$
}

\begin{abstract}
Congenital epulis is an uncommon benign lesion that affects the oral cavity of newborns, and presents histological features which are similar to those of granular cell tumor. The origin of this lesion has not been fully elucidated, and many hypotheses are considered due to the large variety of cell types observed in histological sections. Epulis development occurs further in the prenatal period, and is more common in newborn females, frequently in the maxilla. This lesion usually is presentend as a nodule covered by normal oral mucosa, which in some cases, interferes with baby's breathing and feeding. This report describes the case of a two-month-old male baby who presented a pedunculated intraoral lesion in the mandibular alveolar ridge. Histological sections revealed presence of mucosal fragments with atrophic squamous stratified epithelium, and fibrous connective tissue composed of cells with granular and eosinophilic cytoplasm. A few days after initial exam, the lesion detached from alveolar ridge, and healed spontaneously.
\end{abstract}

Indexing terms: Gingival diseases. Gingival neoplasms. Infant newborn.

\section{Resumo}

A epúlide congênita é uma lesão benigna rara que acomete a cavidade oral de recém-nascidos e apresenta características histológicas semelhantes às do tumor de células granulares. A origem da lesão ainda não foi completamente elucidada, e as muitas hipóteses a respeito de sua histogênese baseiam-se na grande variedade de tipos celulares observados nos cortes histológicos. A epúlide desenvolve-se ainda no período pré-natal, e é mais comum em recém-nascidos do sexo feminino, ocorrendo com mais freqüência na maxila. Esta lesão costuma apresentar-se como um nódulo coberto por mucosa oral normal que, em alguns casos, interfere na respiração e na alimentação do bebê. Esse artigo descreve o caso de um bebê do gênero masculino, leucoderma, de dois meses de idade, que apresentava lesão intra-oral pediculada com implantação débil na região alveolar da mandíbula. Cortes histológicos revelaram a presença de fragmento de mucosa revestido por epitélio pavimentoso estratificado atrófico, e de tecido conjuntivo fibroso composto de células com citoplasma granular e eosinofílico abundante. Alguns dias após o exame inicial, a lesão desprendeu-se do rebordo alveolar, sofrendo resolução espontânea.

Termos de indexação: Doenças da gengiva. Neoplasias gengivais. Recém-nascido.

\section{INTRODUCTION}

Congenital epulis is a lesion with benign behavior, which affects the oral cavity of newborns. It was first described by Neumann in 18711-3, and has also been denominated congenital granular cell lesion ${ }^{2,4}$.

The origin of congenital epulis has not yet been completely elucidated, and the many hypotheses with respect to its histogenesis are based on the large variety

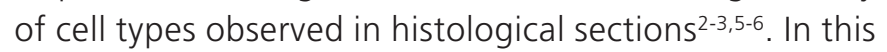
context, epulis may arise from neurogenic, fibroblastic, histiocytic, myoblastic and odontogenic cells $s^{3}$. However, the most accepted hypothesis is that this lesion originates from primitive mesenchymal cells, that undergo granular cytoplasmic transformations caused by an unknown factor.

Moreover, epulis develops in the prenatal period, and its growth appears to be influenced by hormonal factors ${ }^{1,3}$. This hypothesis is corroborated by the fact that epulis does not increase in size after birth, and frequently begins to regress. In cases that an increase in the dimension of the lesion have been reported after the

\footnotetext{
${ }^{1}$ Universidade Federal do Pará, Instituto de Ciências da Saúde, Faculdade de Odontologia Rua Augusto Corrêa, 1, Cidade Universitária Prof. José da Silveira Neto, Guamá, 66075-110, Belém, PA, Brasil. Correspondência para / Correspondence to: JJV PINHEIRO. E-mail: <radface@hotmail.com>

${ }^{2}$ Centro Universitário do Pará, Curso de Odontologia. Belém, PA, Brasil.

${ }^{3}$ Universidade de São Paulo, Faculdade de Odontologia, Laboratório de Imagem em 3D. São Paulo, SP, Brasil.
} 
baby's birth, an inflammatory process and formation of edema, caused by traumatic factors may have occurred ${ }^{2}$.

The aim of this study was to analyze the epidemiological, clinical and histological aspects of epulis of the newborn, by means of presentation of a clinical case report.

\section{CLINICAL CASE}

The mother of a 2-mont-old baby, male gender, Caucasian, sought the oral diagnosis service to evaluate her son. The mother reported the baby had difficulty in feeding due to a "problem in the mouth" since birth. On clinical exam, a lesion was observed in the mucosa of the mandibular alveolar ridge, with a nodular aspect and pedunculated base, weakly implanted in the mucosa. The lesion presented a smooth surface, normal coloring with erythematous base, measuring approximately $1 \mathrm{~cm}$ in diameter (Figure 1). The initial diagnosis was congenital epulis. The radiographic image of the region revealed the presence of premature eruption of tooth 71, and a tenuous radiopaque image circumscribing this tooth, corresponding to the lesion (Figure 2). On this occasion, the mother was informed that it would be necessary to perform an incisional biopsy for the purposes of treatment and diagnosis. After seven days, the person responsible for the patient returned to the diagnostic service with the nodule wrapped in a diaper, informing that the lesion had assumed "a purple color and had fallen off" while the baby was crying, which made her seek immediate attendance. A new clinical exam demonstrated that the mandibular alveolar ridge presented no remnant of the lesion (Figure 3). The tissue was then fixed in 10\% formol and afterwards sent for anatomopathological exam.

The histological sections revealed the presence of a fragment of mucosa covered by pavimentous stratified atrophic epithelium (Figure 4A). The lamina propria was constituted of fibrous connective tissue composed of voluminous, round or oval cells, with abundant granular eosinophilic cytoplasm (Figure 4B). Based on these data, the histopathological diagnosis was of congenital epulis.

This clinical report, and the exhibition of the images here presented, were authorized by the person responsible for the patient.

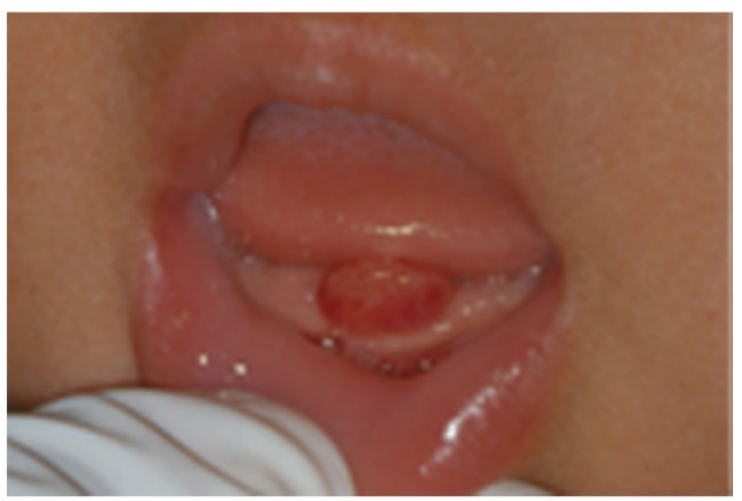

Figure 1. Clinical aspect of the lesion.

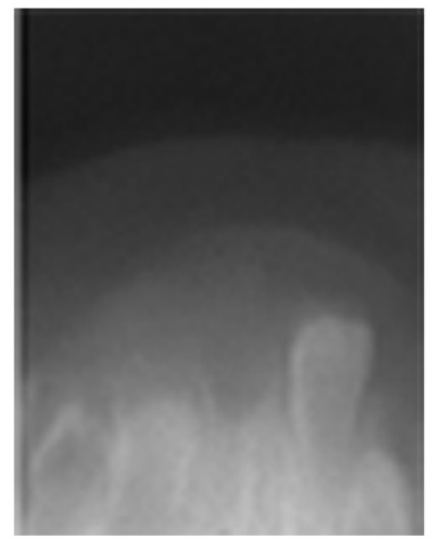

Figure 2. Radiographic characteristic of the lesion Note the tendency toward premature eruption of tooth 71

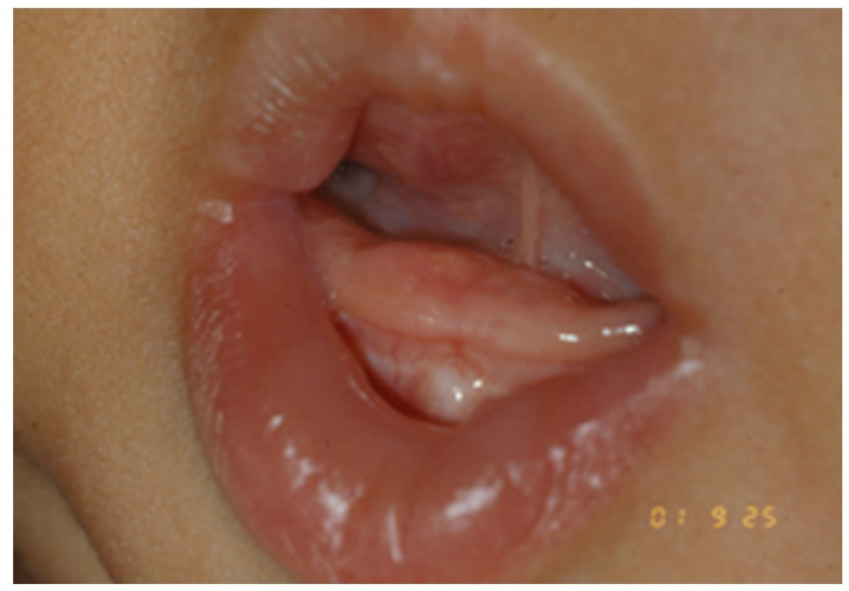

Figure 3. Clinical aspect after spontaneous regression of the lesion. 

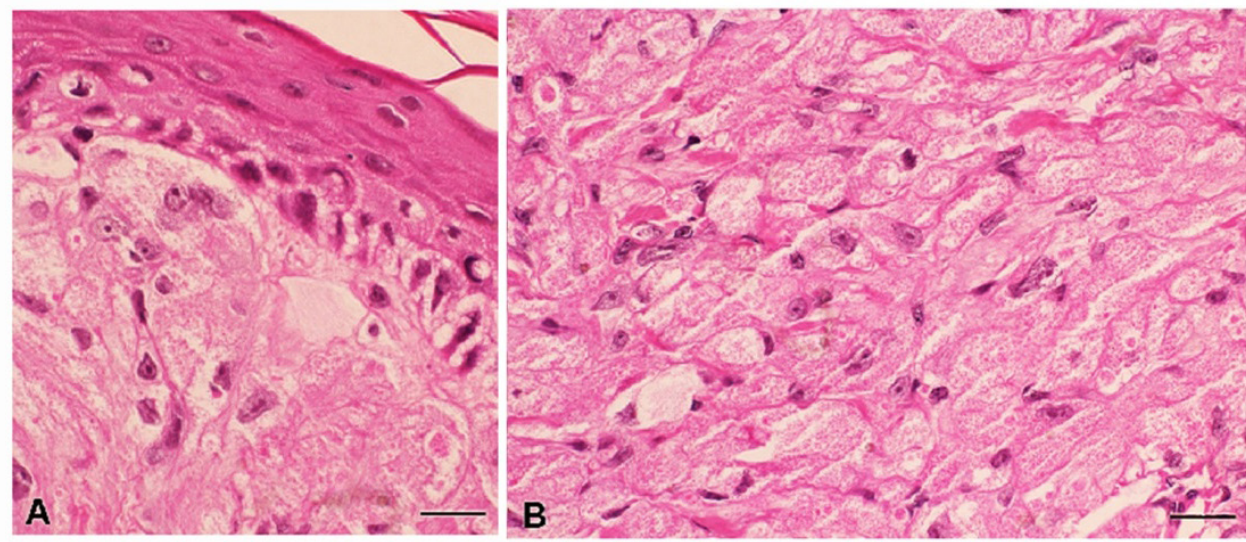

Figure 4. A) histopathological aspect of the lesion, presenting pavimentous, stratified, atrophic epithelium; b) presence of voluminous cells with granular eosinophilic cytoplasm characteristic of the lesion. Scales: $20 \mu \mathrm{m}$.

\section{DISCUSSION}

Of rare occurrence, congenital epulis predominantly affects children of the female gender ${ }^{1-4,7-12}$, with studies reporting a ratio of up to 9:1 between girls and boys. Some authors have attributed this phenomenon to a possible hormonal influence ${ }^{8}$. However, no significant levels of estrogen and progesterone receptors have been found in immunohistochemical analyses of the lesion, which contradicts this theory ${ }^{1,7}$.

Clinically, congenital epulis has been shown to be a nodular mass, with a pedunculated or sessile base, firmly implanted, covered by normal colored mucosa ${ }^{10}$, most frequently affecting the anterior region of the maxilla ${ }^{2-3}$. In addition to the clinical case reported having developed in the mandible, it affected a child of the male gender, which is in contrast with the literature.

Solitary lesions are common findings, however, in approximately $10 \%$ of cases, multiple lesions are found ${ }^{1,3,13-14}$. In spite of almost exclusively affecting the alveolar ridge, there are reports involving the dorsum of the tongue in case of multiple epulides ${ }^{2}$. Its size is extremely variable, and there have been situations in which the extensive volume of the lesion has made it possible to detect it in ultrasound exams in the prenatal period.

Complications inherent to epulis are related to respiratory function and the act of feeding, which may be greatly affected ${ }^{10,14-17}$ In the case presented, the person responsible for the baby affirmed that he had difficulty during feeding.

The histological findings revealed non encapsulated aggregates of large cells with granular eosinophilic cytoplasm and small nuclei. Normal mitotic figures rich in blood supply were observed in the tissue. The lesion was lined by a thin layer of connective tissue covered by keratinized squamous epithelium ${ }^{3}$. Infiltrates of polymorphonuclear cells and foci of ulceration may eventually be found ${ }^{1-2}$. Microscopically, epulis is similar to the granular cell tumor (GCT); however, this tumor characteristically presents a pseudoepitheliomatous hyperplasia which is absent in congenital epulis. Furthermore, immunohistochemical analyses did not reveal the expression of S-100 protein, typical of $\mathrm{GCT}^{1,4,18}$.

The differential diagnosis of congenital epulis, in addition to granular cell tumor, includes diseases such as rhabdomyosarcoma, chondrogenic and osteogenic sarcomas ${ }^{3}$, hemangioma, fibroma and granuloma ${ }^{8}$.

Surgical excision is the treatment of choice, and frequently only requires simple section of the peduncle. There is also the possibility of regression by spontaneous necrosis related to the small thickness of the pedicle ${ }^{10}$, as occurred in this case. There are no reports of recurrence in the literature, even when the lesion was not completely removed2-3,10.

In spite of the aggressive appearance, the lesion does not invade bone tissue and does not interfere in subsequent tooth eruption ${ }^{3}$. In this report, the radiograph of the lesion site denoted the presence of premature eruption of tooth 71. During this research no data were found with reference to this type of occurrence, or any apparent causes for this phenomenon.

\section{CONCLUSION}

In spite of not being a common nosology, epulis of the newborn deserves to be pointed out by virtue of its 
sometimes extremely aggressive appearance, and clinical complications. Knowledge about its main characteristics may be useful for differentiating it from more serious diseases, as well as to tranquilize apprehensive parents who seek professional help to resolve the problem.

\section{Collaborators}

JJV PINHEIRO coordinate preparation of the work, and was responsible for the histopathological diagnosis of the case, and writing the article. AS SIQUEIRA, MRD CARVALHO and ACD MONTEIRO participated in writing the article and treatment of images. GR PINHEIRO made the clinical diagnosis, performed acquisition of images and participated in writing the article. LR PINHEIRO was

\section{REFERENCES}

1. Leocata P, Bifaretti G, Saltarelli S, Corbacelli A, Ventura L. Congenital (Granular cell) epulis of the newborn: a case report with immunohistochemical study on the histogenesis. Ann Saudi Med. 1999;19(6):527-9.

2. Loyola AM, Gatti AF, Pinto Júnior DS, Mesquita RA. Alveolar and extra-alveolar granular cell lesions of the newborn: report of a case and review of the literature. Oral Surg Oral Med Oral Pathol. 1997;84(6):668-71. doi: 10.1016/S1079-2104(97)90370-X.

3. Merrett SJ, Crawford PJM. Congenital epulis of the newborn: a case report. Inter J Paediatric Dent. 2003;13(2):127-9. doi: 10.1046/j.1365-263X.2003.00435.x.

4. Damm DD, Cibull ML, Gissler RH, Neville BW, Bowden CM, Lehmann JE. Investigation into the histogenesis of congenital epulis of the newborn. Oral Surg Oral Med Oral Pathol. 1993;76(2):205-12. doi: 10.1016/0030-4220(93)90206-J

5. Blinkhorn AS, Attwood DA. Congenital epulis interfering with feeding in a day-old baby girl. Dent Update. 1990;17(8):346.

6. Kaiserling E, Ruck P, Xiao JC. Congenital epulis and granular cell tumor: a histologic and immunohistochemical study. Oral Surg Oral Med Oral Pathol. 1995;80(6):687-97. doi: 10.1016/S10792104(05)80253-7.

7. Tucker MC, Rusnock EJ, Azumi N, Hoy GR, Lack EE. Gingival granular cell tumors of the newborn. An ultrastructural and immunohistochemical study. Arch Pathol Lab Med. 1990;114(9):895-8.

8. Evans DA. Congenital epulis. Otolaryngol Head Neck Surg $2001 ; 125(3): 283-4$

9 Junquera LM, Vicente JC, Vega JA, Losa JL, Albertos JL, LópezArranz JS. Granular-cell tumours: an immunohistochemical study. Brit J Oral Maxillofac Surg. 1997;35(3):180-4. responsible for taking the radiographs, treatment of images and writing the article. All the authors worked together for the diagnosis, follow-up and preparation of the work.

\section{Acknowledgements}

The authors thank the São Paulo State Research Support Foundation (FAPESP) for granting a doctoral scholarship to Adriane Sousa de Siqueira (2009/17336-6). They also thank the National Council for Scientific and Technological Development ("Conselho Nacional de Desenvolvimento Científico e Tecnológico $(\mathrm{CNPq}))^{\prime \prime}$, for granting a post-doctoral scholarship to João de Jesus Viana Pinheiro (504667/2008-4).

10. Michel B, Couly G. Tumeurs et dysplasies tumorales de la cavité buccale du nouveau-né et du nourrisson. EMC-Dentisterie. 2004;1(3):214-27. doi: 10.1016/j.emcden.2004.02.003

11. Uglesic V, Bagatin M. Congenital epulis: a case report. Br J Oral Maxillofac Surg. 1988;26(3):237-40.

12. Azevedo RA, Galli GB, Pereira CL, Pires MSM. Epúlide congênita. RGO, Rev Gaúch Odontol. 2005;53(3):206-9.

13. Lack EE, Worsham GF, Callihan MD, Crawford BE, Vawter GE. Gingival granular cell tumors of the newborn (congenital "epulis"): a clinical and pathologic study of 21 patients. Am J Surg Pathol. 1981;5(1):37-46.

14. Eghbalian F, Monsef $A$. Congenital epulis in the newborn, review of the literature and a case report. J Pediatr Hematol Oncol. 2009;31(3);198-9. doi: 10.1097/MPH.0b013e31818ab2f7.

15. Kusukawua J, Kuhara S, Koga C, Inoue T. Congenital granular cell tumor (congenital epulis) in the fetus: a case report. J Oral Maxillofac Surg. 1997;55(11):1356-9. doi: 10.1016/S02782391(97)90202-0.

16. Chinidia ML, Awange DO. Congenital epulis of the newborn: a report of two cases. Br Dent J. 1994;176(11):426-8.

17. Guven S, Kaymakci A, Bugday MS, Yilmaz M. Congenital granular cell tumor. J Craniofac Surg. 2009;20(3):976-7

18. Cavalcanti VA, Soares AB, Dipe LR, Furuse C. Tumor de células granulares: relato de caso em uma localização incomun. RGO, Rev Gaúch Odontol. 2008;56(1):89-92. 